\title{
PENINGKATKAN DAYA SAING DAN KUALITAS PRODUK HOME INDUSTRI BATU BATA MERAH MELALUI PENDAMPINGAN SESUAI SNI 15-2094-2000
}

\author{
Rini Pebri Utari ${ }^{1}$, Erwin Rommel ${ }^{2}$, Ernawan Setyono ${ }^{3}$ \\ ${ }^{1,2,3)}$ Program Studi Teknik Sipil, Fakultas Teknik, Universitas Muhammadiyah Malang, Indonesia \\ e-mail : rinipebriutari@umm.ac.id
}

\begin{abstract}
Abstrak
Permasalahan yang dijumpai pada home industri batu bata desa Pakem Kecamatan Wajak Kabupaten Malang, antara lain; kualitas produk masih rendah, belum memiliki standar kerja dan kualitas produksi sesuai dengan peraturan SNI15-2094-2000, sehingga mutu produksi tidak bisa seragam, belum ada manajemen pengelolaan dan pemasaran yang baik (penjualan masih bersifat pasif) serta skill pekerja yang masih rendah. Kegiatan yang telah dilaksanakan untuk mengatasi permasalahan tersebut antara lain; melakukan pendampingan kepada pekerja home industri tentang pembuatan batu bata sesuai standart SNI, pendampingan tentang tata kelola usaha kepada pemilik dan pengelola home industri, bantuan peralatan penunjang home industri, pembuatan modul pembuatan batu bata, pengaturan lokasi dan pemasangan papan nama serta pembuatan media promosi usaha home industri seperti mencetak brosur penjualan, membuat website dan Instagram sebagai direct selling secara on-line. Dari pendampingan ini didapatkan adanya peningkatan kualitas produk batu bata merah sesuai dengan SNI dengan memperbaiki proporsi campuran bahan yang digunakan, serta pengujian kualitas secara berkala. Adapun dari segi produksi mengalami peningkatan seiring dengan bertambanya permintaan konsumen. Adapun capaian lainnya yaitu adanya perbaikan dan penataan tempat usaha menjadi lebih baik dan lebih nyaman baik bagi pekerja maupun bagi konsumen.
\end{abstract}

Kata kunci: Home Industri, Bata Merah, SNI 15-2094-2000,

\begin{abstract}
The problems encountered in the brick home industry in Pakem village, Wajak sub-district, Malang regency, include; Product quality is still low, does not have work standards and production quality in accordance with SNI15-2094-2000 regulations, so that the quality of production cannot be uniform, there is no management and good marketing (sales are still passive) and worker skills are still low. Activities that have been carried out to overcome these problems include; provide assistance to home industrial workers regarding brick making according to SNI standards, assistance on business governance to home industry owners and managers, assistance for home industry support equipment, manufacture of brick making modules, location arrangement and installation of signboards as well as making home business promotion media industries such as printing sales brochures, creating websites and Instagram as direct selling on-line. From this assistance, it was found that there was an increase in the quality of red brick products in accordance with SNI by improving the proportion of the mixture of materials used, as well as periodic quality testing. In terms of production, it has increased along with the increase in consumer demand. Other achievements include improvement and arrangement of business premises to become better and more comfortable for both workers and consumers.
\end{abstract}

Keywords: Home Industry, Red Brick, SNI 15-2094-2000

\section{PENDAHULUAN}

Perkembangan industri konstruksi yang meningkat menuntut kualitas material yang baik pula. Salah satu material utama yang sering digunakan dalam konstruksi adalah batu bata merah yang digunakan sebagai komponen dinding. Batu bata merah adalah salah satu unsur bangunan dalam pembuatan konstruksi bangunan yang terbuat dari tanah lempung ditambah air dengan atau tanpa bahan campuran lain melalui beberapa tahap pengerjaan, seperti menggali, mengolah, mencetak, mengeringkan, membakar pada temperatur tinggi hingga matang dan berubah warna, serta akan 
mengeras seperti batu setelah didinginkan hingga tidak dapat hancur lagi bila direndam dalam air. (Abdurrohmansyah, 2015).

Selain itu, bata merah banyak diminati karena harganya yang dapat dijangkau oleh masyarakat. Dengan meningkatnya pembangunan di Malang, baik dalam bidang perumahan, gedung bertingkat, maupun sarana dan prasarana, maka meningkat pula permintaan pasokan bata merah. Dari segi teknis, bata merah diharuskan memiliki spesifikasi tertentu sesuai dengan SNI 152094-2000 tentang syarat mutu dan cara uji bata merah. Sering dijumpai di pasaran mutu dan kualitas bata merah kurang baik, ukuran tidak siku mudah rapuh, retak-retak pada permukaan, ukuran yang tidak seragam, warna pada penampang bata tidak merata.

Proses produksi bata merah pejal tradisional di Indonesia saat ini masih didominasi oleh industri kecil (home industry). Dimana proses pembuatannya umumnya masih secara tradisional, hal ini dapat kita lihat dari sistem pembakaran batu bata merah yang masih menggunakan tungku. Penggunaan tungku dalam proses pembakaran menggunakan bahan bakar kayu sehingga hasil pembakaran yang diperoleh pun akan bervariasi. Bahan baku utama pembuatan batu bata adalah tanah liat, maka ketersedian tanah liat perlu diananlisis apakah apakah masih mampu mendukung keberlanjuatan industri bata merah dimasa yang akan datang. (Prayoga, 2018)

Kualitas produk yang masih bervariasi juga mempengaruhi kualitas batu bata merah pejal tradisional yang di produksi. Selain itu proses pencampuran bahan yang kurang homogen, ketidakteraturan dan ketidakstabilan komposisi dari proses pembuatan bata merah itu sendiri kurang diperhatikan. Mutu bata merah pejal terdiri dari beberapa komponen mutu. (Syaelendra,2012)

Selain itu pemilihan bahan dasar di dalam pembuatan bata merah pejal tradisional juga perlu diperhatikan, karena juga akan berpengaruh pada mutu serta keawetan bata merah pejal tradisional yang dihasilkan. Oleh karena itu pemilihan bahan dasar yang tepat diharapkan mengurangi kemungkinan timbulnya pengaruh yang merugikan, serta diharapkan dapat meningkatkan kekuatan dan keawetan batu bata merah pejal tradisional. (kardipura,2016)

Program pengabdian yang dilaksanakan oleh Tim Pengabdian Univesritas Muhammadiyah Malang ini berlokasi pada home Industri bata merah yang terletak di desa Pakem di kecamatan Wajak Kabupaten Malang - Jawa Timur ini sudah berdiri sejak tahun 2005. Permasalahan yang dijumpai pada home industri ini antara lain; kualitas produk masih rendah, skill pekerja yang masih rendah, belum memiliki standar kerja dan kualitas produksi sesuai dengan peraturan Standar Nasional Indonesia No 15-2094-2000. Adapun kegiatan ini bertujuan untuk penyelesaian permasalahan yang ada di masyarakat khususnya pada usaha home industri batu bata merah yang ada di Desa Pakem Kecamatan Wajak Kabupaten Malang sehingga dapat mendongkrak perekonomian desa.

\section{METODE}

Untuk mengatasi permasalahan yang terjadi pada home industri batako dan batu bata dilakukan beberapa metode pendekatan dan pelaksanaan :

1) Melakukan studi kasus untuk mengatahui keadaan lokasi, peralatan dan produk batu bata yang dihasilkan oleh home industri desa Pakem Kecamatan Wajak Kabupaten Malang.

2) Memberikan penjelasan tentang standar baku pembuatan batu bata sesuai SNI kepada pengelola home industri tentang upaya untuk meningkatkan kualitas produk. Adapun Persyaratan mutu bata merah meliputi sifat tampak, ukuran dan toleransi, kuat tekan, garam yang membahayakan, kerapatan semu minimum, dan penyerapan air mkasimum yang tercantum dalam dokumen SNI 15-2094-2000.

3) Workshop pendampingan pembuatan batu bata dan tata cara pengujian kualitas batu bata yang sesuai standar SNI kepada pekerja di home industri. Kegiatan ini dilaksanankan bersama pekerja di home industry desa Pakem Kecamatan Wajak Kabupaten Malang dengan Laboratorium Batu bata Universitas Muhammadiyah Malang

4) Memberikan pendampingan mengenai teknik pemasaran lainnya seperti pembuatan brosur, penyebaran melalui media cetak, mencari mitra kerja dan menitipkan hasil produk melalui toko-toko bangunan serta promosi melalui media online sperti blog, dan sebagainya. 


\section{HASIL DAN PEMBAHASAN}

1) Pendampingan Pembuatan dan pengujian Batu Bata Merah (WorkShop) singkat sesuai SNI
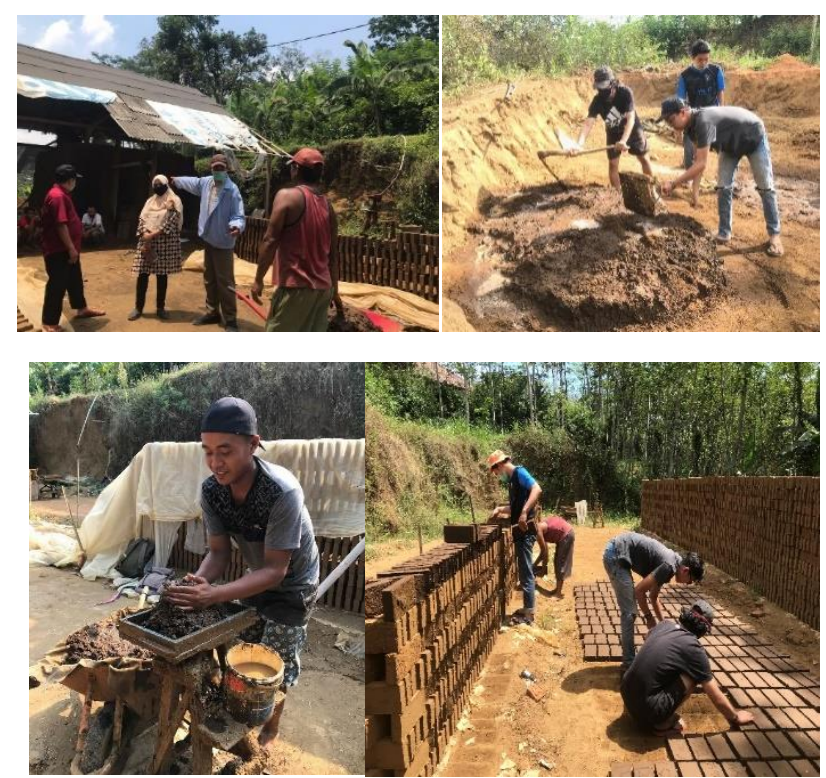

Gambar 1. Workshop Pendampingan proses produksi sesuai SNI

Awalnya kegiatan produksi yang dilakukan di Home Industri desa Wajak ini dilakukan dengan peralatan seadaanya dan proporsi pencampuran tidak sesuai standart baku SNI, setelah diadakan pendampingan mulai dari pemelihan kualitas, proporsi pencampuran dan pembenahan metode maka memberikan hasil meningkatnya skill dan kualitas pekerja serta kualitas produk batu bata.

2) Pada kondisi eksisting pada lokasi home industri, peralatan yang digunakan masih sangat tradisional dan kurang produktif. Peralatan cukup terbatas dan sudah mengalami aus. Oleh karena itu, dilakukan pembaharuan alat produksi oleh tim pengabdian yaitu archo, sekop, cetakan besi dan perbaikan mesin adukan spesi sehingga dapat meningkatkan produktivitas para pekerja.
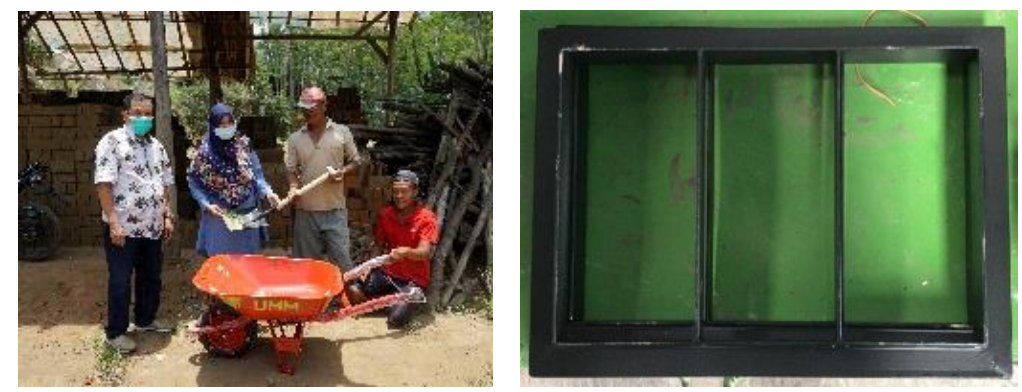

Gambar 2. Penyerahan alat produksi baru

3) Pengujian Kualitas bata bekerjasama dengan Laboratorium Beton Teknik Sipil UMM. Setelah adanya pendamping, kualitas produk meningkat dan didapat rata-rata kuat tekan bata
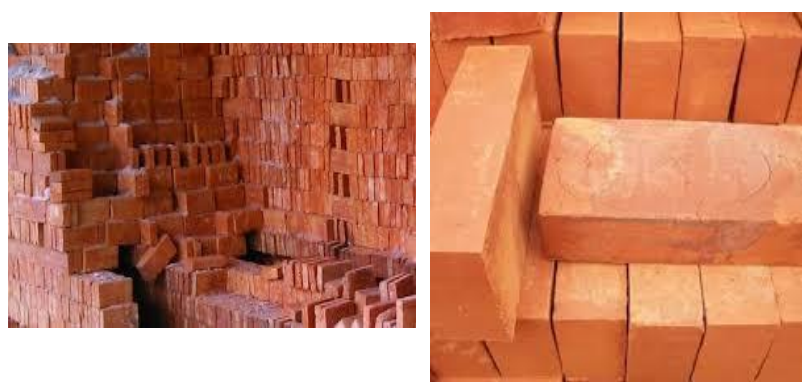

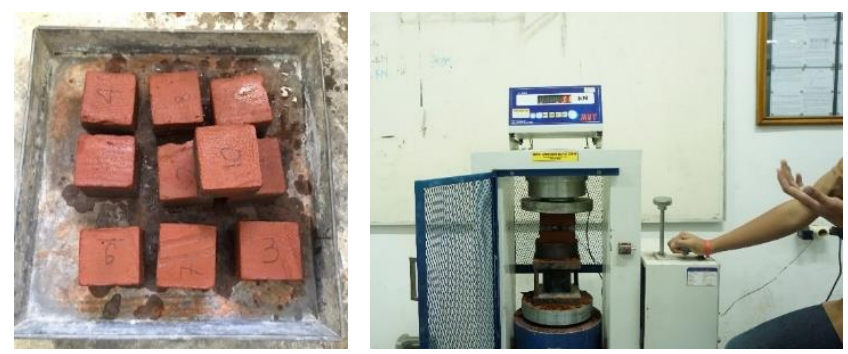

Gambar 3. Hasil Pembakaran (setelah pendampingan)

Tabel 4. Proses Pengujian Laboratorium

Tabel 1. Hasil Pengujian bata merah (setelah pendampingan)

\begin{tabular}{ccccccc}
\hline $\begin{array}{c}\text { Benda } \\
\text { Uji }\end{array}$ & $\begin{array}{c}\text { Luas Penampang } \\
(\mathrm{cm} 2)\end{array}$ & $\begin{array}{c}\text { Hasil } \\
(k N)\end{array}$ & $\begin{array}{c}\text { Kuat } \\
\text { Tekan } \\
(\mathrm{kN} / \mathrm{cm} 2)\end{array}$ & $\begin{array}{c}\text { Kuat } \\
\text { Tekan } \\
(\mathrm{Kg} / \mathrm{cm} 2)\end{array}$ & $\begin{array}{c}\text { Konversi } \\
(\text { Mpa })\end{array}$ & $\begin{array}{c}\text { Rata-rata } \\
(\text { Mpa })\end{array}$ \\
1 & 144 & 60.7 & 0.422 & 42.574 & 4.86 & \\
2 & 144 & 61.1 & 0.424 & 42.855 & 5.02 & \\
3 & 144 & 65 & 0.451 & 45.590 & 5.13 & \\
4 & 144 & 59.9 & 0.416 & 42.013 & 5.22 & \\
5 & 144 & 68 & 0.472 & 47.694 & 4.97 & 5.01 \\
6 & 144 & 65.3 & 0.453 & 45.801 & 5.25 & \\
7 & 144 & 52.5 & 0.365 & 36.823 & 5.27 & \\
8 & 144 & 58.9 & 0.409 & 41.312 & 5.08 & \\
9 & 144 & 70.1 & 0.487 & 49.167 & 5.16 & \\
10 & 144 & 66.1 & 0.459 & 46.362 & 5.19 & \\
Sumber : Pengolahan Data & & & &
\end{tabular}

Pengujian dilakukan berdasarkan acuan tata cara pengujian bata merah pada SNI 15-20942000 tentang Bata merah pejal untuk pasangan dinding. Saat belum diadakan pendampingan, home industry ini memiliki kualitas dibawah standart SNI, namun setelah dilakukan pendampingan, dari hasil pengujian didapat rata-rata kuat tekan bata merah produksi home industri Pak Sanipan sebesar 5,01 Mpa. Maka dengan itu, batu bata merah ini bisa dikatakan sudah masuk ke skala mutu SNI untuk skala kelas I, dan setelah dilakukan pendampingan dari segi kualitas tampak, batu bata merah ini sudah memiliki stuktur yang baik dan kokoh.

Namun terkadang batu bata yang telah masuk ke kelasn standart harus dilakukan penelitian dan pengujian ulang kembali, seperti di dalam penelitian (Indra, 2013) mengatakan secara standar produksi batu bata ini memang telah masuk kualitas, namun masih perlu upaya lain untuk meningkatkan kualitas dengan berbagai macam cara diantaranya dengan menambah bahan penguat pada bahan baku dan menaikkan temperatur bakar dari batu bata itu sendiri.

4) Pendampingan pemasangan nama, penataan lokasi, pengaturan hasil produksi, display produk, dan tempat istirahat para pekerjan sehingga areal kerja lebih tertata rapi. 

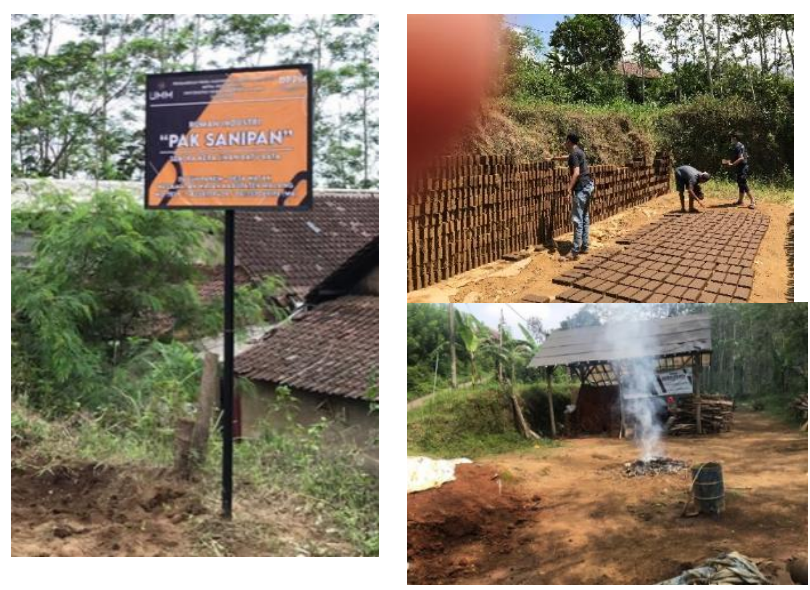

Gambar 5. Penataan Areal Lokasi

Pengaturan lokasi kerja yang dimaksud adalah pengaturan tata letak proses produksi, tataletak pengaturan hasil produksi, display produk, dan tempat istirahat para pekerja. Sedangkan perbaikan lokasi dilakukan dengan merapikan dan membersihkan lokasi secara berkala sehingga lokasi menjadi lebih tapi, nyaman dan alur kerja menjadi lebih tertata.

5) Pembuatan Brosur dan website penyebaran produk sebagai upaya promosi. Dengan adanya promosi melalui media online berdampak meningkatnya permintaan konsumen.

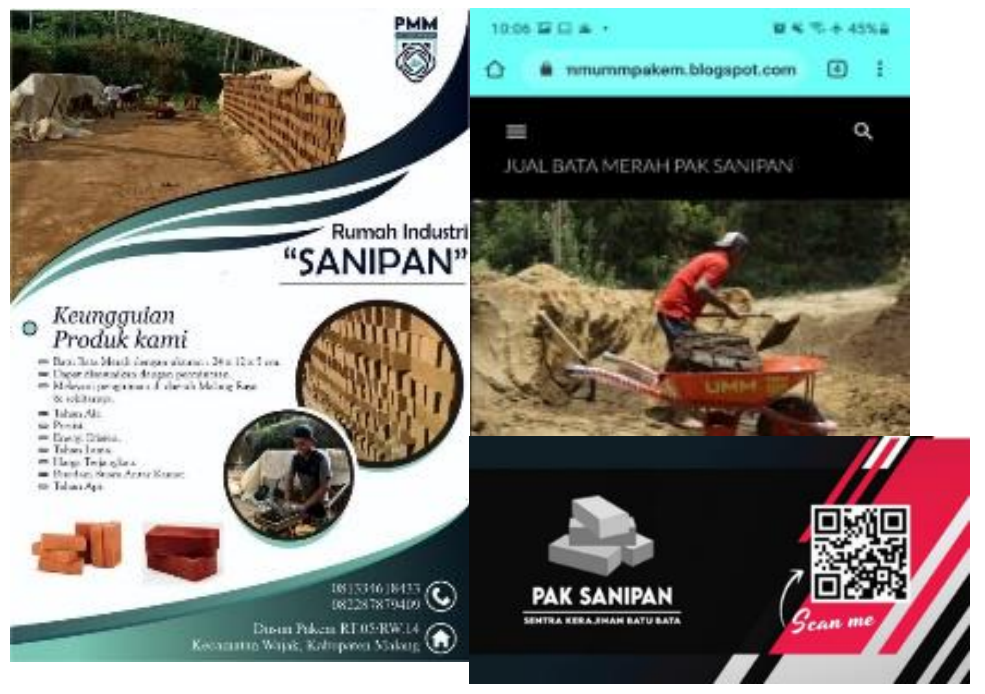

\section{SIMPULAN}

Gambar 6. Tampilan brosur dan website home industri

1. Setelah diadakan pendampingan, para pekerja memiliki tambahan keahlian/skill tentang tata cara pembuatan batubata yang tepat, pemilihan bahan yang benar dan cara pengujian kualitas paving sesuai dengan SNI, hal ini dapat dilihat dari kualitas produk batu bata yang dihasilkan lebih baikyaitu sebesar 5.01 Mpa dan dapat dilihat dari struktur lebih kokoh dan bentuk yang lebih simetris.

2. Setelah diadakan pengaturan dan perbaikan lokasi kerja, terlihat lokasi kerja lebih tertata, tempat penataan dan display hasil produk lebih rapi dan home industri tampak lebih bagus dari sebelumnya.

3. Dengan adannya pemasangan papan nama pada pintu masuk home industry diharapkan para konsumen yang ingin membeli produk dapat mudah menemukan lokasi home industri.

4. Dengan pemberian bantuan peralatan yang baru dan perbaikan mesin pengaduk campuran dapat mempercepat produktivitas produksi para pekerja 
5. Salah satu kegiatan promosi yang dilakukan adalah melalui media cetak/brosur dan kartu nama yang nantinya brosur akan disebar kepada konsumen, proyek proyek perumahan, dan ditokotoko bangunan.

\section{SARAN}

- Perlu dilakukan manajemen produksi khususnya cashflow biaya produksi dan income penjualan sehingga diketahui dengan tepat besarnya keuntungan yang didapatkan.

- Perlu diadakan ide-ide promosi untuk menarik minat konsumen, misalnya dengan memberikan diskon setiap pembelian jumlah tertentu, ataupun dengan cara lainnya.

\section{UCAPAN TERIMA KASIH}

Rektor Universitas Muhammadiyah Malang atas izin, pembinaannya, dan motivasinya sehingga kegiatan Tri Dharma Pergurun Tinggi ini terlaksana dengan baik. Kepala Direktorat Penelitian dan Pengabdian kepada Masyarakat (DPPM) Universitas Muhammadiyah Malang atas dukungan dan araannya melakukan kegiatan Pengabdian Kelompok ini dengan

\section{DAFTAR PUSTAKA}

Abdurrohmansyah. 2015. Studi Kuat Tekan Batu Bata menggunakan Bahan Fly Ash berdasarkan SNI.Jurnal Ilmiah. Universitas Lampung.

Indra, A. (2013). Kuat Tekan (Compression Strength) Komposit Lempung/Pasir pada Aplikasi Bata Merah Daerah Payakumbuh Sumbar. Jurnal Teknik Mesin (JTM), 1(2).

Kartadipura, R. H. (2016). Analisa Strategi Pemilihan Material Pasangan Dinding. InfoTeknik, 14(2), 158-170.

Prayoga, Y. (2018). Peranan Industri Batu Bata Terhadap Tingkat Kemiskinan Di Kecamatan Rantau Selatan Kabupaten Labuhan Batu. Ecobisma (Jurnal Ekonomi, Bisnis dan Manajemen), 5(2), 47-53.

Standar Nasional Indonesia. 2000. SNI 15-2094-2000: Mutu dan Cara Uji Bata Merah Pejal, Departermen Pemukiman dan Prasarana Wilayah. Bandung.

Syaelendra, Tommy. 2012. Analisis Mutu Batu Bata Merah Pejal Tradisional Di Jakarta Terhadap SNI 15-2094-2000. Jurnal Menara Jurusan Teknik Sipil FT.UNJ Volume VII No.1 - Januari 2012. 